\title{
Patients Satisfaction with Pharmaceutical Care and Associated Factors in the Southwestern Ethiopia
}

\author{
Gemmechu Hasen (iD) ${ }^{1,2}$ \\ Bedaso Negeso' \\ 'Jimma University, Institute of Health, \\ School of Pharmacy, Jimma, Oromia, \\ Ethiopia; ${ }^{2}$ Jimma University Laboratory \\ Drug Quality (JuLaDQ), Jimma, Oromia, \\ Ethiopia
}

Background: An evaluation of patient satisfaction with service provided in the health care system has been globally recognized as the measure of health care service quality. However, there is a lack of research findings that indicate patient satisfaction with newly implemented patient-oriented pharmaceutical care (PC) service provided by clinical pharmacists in Ethiopia. Therefore, the current study is aimed to determine the level of patient satisfaction and associated factors with PC service provided by clinical pharmacists in the Southwestern Ethiopia.

Methodology: A facility-based cross-sectional study design was employed among patients admitted to Medical wards in Jimma University Medical Center (JUMC) (n=219) from May to June 2021. The pretested interviewer-administered questionnaire containing structured questions on a 5-point Likert scale was appropriately completed and returned for statistical analysis. For the analysis of data, Statistical Package for Social Sciences (SPSS) was used. The associations between status of patient satisfaction and predictors were determined at $5 \%$ $(p<0.05)$ level of significance by employing multivariate logistic regression.

Results: The current study revealed that more than half $(56 \%)$ of the respondents were satisfied with clinical pharmacy service. From 30\% of drug therapy problems (DTPs) reported, non-adherence was the most prevalent $(11.4 \%)$, while the dose being too low and adverse effects $(0.9 \%)$ were the least reported. Moreover, the assignment particular clinical pharmacist (AOR: 2.091, 95\% CI: 1.028, 4.255), previous admission (AOR: 0.459, 95\% CI: $0.244,0.86$ ), number of medications taken per day (AOR: $1.929,95 \%$ CI: 1.996, 3.739) and length of hospital stay (AOR: $2.236,95 \% \mathrm{CI}: 1.124,4.446)$ were significantly associated with patient satisfaction.

Conclusion: The present study revealed that patient satisfaction towards PC was low. Lack of specific clinical pharmacist assignment, previous history of admission, number of medications taken per day and length of hospital stay are revealed as the major factors affecting the level of satisfaction. In addition, current findings implicate that clinical pharmacist collaboration with a multidisciplinary team is essential to increase patient satisfaction.

Keywords: Patient, Satisfaction, Pharmaceutical care, Ethiopia

\section{Introduction}

Over the past several decades, the pharmacy profession is experiencing rapid growth and development, particularly in transitions from medications compounding and dispensing to a patient-oriented pharmaceutical care (PC) service. ${ }^{1,2}$ PC is the responsible provision of drug therapy for the purpose of achieving definite outcomes that improve patient's quality of life, ${ }^{3}$ mainly provided by clinical pharmacists. $^{4}$ In recent years, its implementation in the health care system has been evidenced by highlighting the benefits of PC particularly, in the reduction of
Correspondence: Gemmechu Hasen Jimma University, P.O.Box: 378, Jimma, Oromia, Ethiopia

Email gemmechuhasen2009@gmail.com 
preventable drug-related morbidity and mortality. ${ }^{5-7}$ Moreover, the World Health Organization (WHO) and the International Pharmaceutical Federation have indicated the importance of changing the traditional role of pharmacists from product-oriented towards a patient-centered practice by considering the high demand of health issues with myriad range of chronic diseases and poor adherence to prescribed medicines. ${ }^{8}$ Since then, many articles have highlighted the outcomes of PC implementation in the health care system throughout the world, ${ }^{9-15}$ even during the recent COVID-19 pandemic. ${ }^{16}$ For instance, preventing medication errors, reducing the incidence of adverse drug reaction, and saving medical costs are the main benefits of PC implementation reported in the aforementioned studies. Besides this, it has been revealed that pharmacists direct patients care, benefit patients and the health care services while appearing to be a highly costeffective option. ${ }^{17-19}$

However, health care quality including PC has become a global concern that occasioned the healthcare industry to make rapid changes to meet the growing demands of its patient population. ${ }^{20}$ Thus, evaluating PC service is very crucial to ensure and improve quality in pharmacist's decision making to optimize health care resources. ${ }^{21}$ The evaluation of patient's satisfaction, an integral healthcare quality component, is a very important indicator of quality assessment in a health care system as it offers information on the provider's success at meeting the expectations of most relevance to the client and a key determinant of patients' perspective behavioural intention. ${ }^{22-24}$ In Ethiopia, PC service has been newly implemented in different public hospitals in which Jimma University Medical Center is a pioneer in launching of the service. ${ }^{25}$ Currently, in accordance with the National Clinical Pharmacy Service Directive developed by the Federal Ministry of Health of Ethiopia, PC services are being provided by clinical pharmacists, which includes patient assessment, developing care plan, and follow up and evaluation for continuous care of patients. ${ }^{26}$ However, since its implementation there is no study that determines the patient's satisfaction with PC service provided by clinical pharmacists, particularly in south west of Ethiopia. A recent study conducted on patients' satisfaction with PC service among HIV/AIDS patients has revealed a low level of satisfaction. ${ }^{27}$ This finding was specific and did not cover the holistic patientoriented pharmacy practice. Thus, it is very crucial to assess the status of patient's satisfaction towards PC to ensure and improve the quality of this newly implemented service in Ethiopia. Therefore, the current study was aimed to determine the level of patient satisfaction and associated factor with PC provided by clinical pharmacists in the south west Ethiopia.

\section{Methodology}

\section{Study Design and Study Site}

A facility based cross-sectional study design was employed among patients admitted to Medical wards in Jimma University Medical Center (JUMC) $(n=219)$ from May to June, 2021. Geographically, Jimma University Medical Center is located in Jimma Town, and $350 \mathrm{~km}$ away from Addis Ababa, the capital of Ethiopia. The center provides the major services encompassing nine medicals and other clinical and diagnostic departments. Approximately, 15,000 inpatients and 160,000 out patients, 11,000 emergency cases, and 4500 deliveries came to the center in one year from a catchment population of about 15 million. $^{28}$

\section{Sample Population, Size, and Sampling Technique}

The sample size was determined using Raosoft sample size calculator. ${ }^{29}$ A sample size consisted of 234 patients was calculated by considering a 5\% margin of error, $95 \%$ confidence interval, and $50 \%$ distribution response for an approximate population of 600 (the total patients expected to be admitted to medical wards of JUMC during period of one month). Letting 5\% dropouts, 245 participants were included in the study. All adult patients aged 18 years or older admitted to medical wards with at least a 24 hour hospital stay who provided a written informed consent were allowed to participate in the study while unconscious patients and those who refused to give the consent were excluded from the study.

\section{Data Collection Procedure}

For data collection, the questionnaire was designed based on extensive review of previous literatures. ${ }^{20-23,25,27}$ Face validity and as well as readability of the questionnaire has been examined by four experts, paying attentions on easy comprehension of the questionnaire to gear to general populations. Moreover, an English version of the questionnaire was translated to local languages (Afaan Oromo and Amharic) and reversed back to English for the purpose of consistency. The pre-test was conducted on $5 \%$ of populations to check acceptability and consistency data tools 
before commencing the actual study. Based on pre-tested result, questions that could lead to bias were eliminated. The final questionnaire was supplied as Supplementary File. Accordingly, data related to sociodemographic characteristics of the patients (gender, age, residence, marital status, educational level, occupational status, supporting or helping person, assignment of particular clinical pharmacist and patient admission related information (previous admission, presence of comorbidity, presence of adverse effects, number of drug taken per day, length of hospital stay) were collected by using interviewer administered questionnaire. Similarly, patient satisfaction with PC was evaluated using Likert scale questions. Moreover, prevalence, types and causes of drug therapy problem (DTP) were recorded from patient medical records by using semi structured data extraction formats from medical records of the patients. The Likert items were calculated on a 1-5 response scale; strongly satisfied (5), satisfied (4), neutral (3), dissatisfied (2) and strongly dissatisfied (1) with objective of determining the level of patient satisfaction with PC service. To ensure this objective, satisfaction level of patients was assessed; their response was dichotomized into unsatisfied and satisfied after computing the overall mean, from each calculated mean score of patients satisfaction. Accordingly, satisfied earn mean score of greater than or equal to overall mean, while unsatisfied possessed a mean score less than the overall mean.

\section{Statistical Analysis}

Based on appropriate coding and scoring formats, all filled questionnaires were checked to ensure their completeness before they were manually entered into the Statistical Package for Social Science (SPSS) version 21.0 (Chicago, SPSS Inc.). The descriptive statistics were used to summarize the results. Bivariate logistic regression was used to check the association between the outcomes (satisfied and unsatisfied) and independent variables (gender, age, residence, marital status, educational level, occupational status, supporting or helping person, particular clinical pharmacist heir, Previous admission, presence of comorbidity, presence of adverse effects, number of drug taken per day, length of hospital stay). Then, multivariate logistic regression was employed for independent variables possessing a p-value of less than 0.05 to identify the predictor's for patient's satisfaction at 5\% level of significance.

\section{Results}

\section{Characteristics of Study Participants}

From a sample size consisted of 245 participants, 219 patients responded in the study providing a $89.4 \%$ response rate. Among study subjects, the majority of respondents $(n=135,61.4 \%)$ were males and married $(n=155,70.8 \%)$. Around $70 \%$ of study participants were from a rural area, and the highest percentage of their age groups was between 21 - to 30-years-old. With regard to occupation, more than half $(n=117,53.4 \%)$ of respondents were farmers. Moreover, around $54 \%$ of respondents had no formal education and most of the participants were supported by their spouse (Table 1).

\section{Patient and Admission Related Characteristics}

Out of the study subjects, $(n=113,51.6 \%)$ of the respondents had a previous history of admission. Around $86 \%$ of respondents presented with comorbid, and ( $n=41,19.2 \%)$ had developed an adverse effect with medication used. About $70.3 \%$ of patients responded that particular clinical pharmacists had followed up with them about their medication. Concerning length of hospital stay around 48\% stayed less than two weeks, and $30.1 \%$ of DTP were documented (Table 2). Among DTP identified, nonadherence was more prevalent (11.4\%) followed by needs additional therapy (11\%) while the dose too low and adverse effect $(0.9 \%)$ were the least reported (Figure 1).

\section{Level of Patient's Satisfaction with Pharmaceutical Care}

Assessment of the patient's satisfaction with PC was based on seven items assessed by five points Likert scale, which revealed the overall mean to be $2.98 \pm 0.67$ standard deviation. In addition, the dichotomized levels of patient satisfaction based on overall mean showed, more than half (56\%) of respondents were satisfied with PC (Figure 2). A majority of patients responded 'satisfied' to 'very satisfied' for item like satisfaction with medication reconciliation, counselling of storage condition and instructions, and time spent with pharmacist while they responded dissatisfied with encouragement on adherence (Table 3). The detail of evaluation of patient satisfaction with PC using Likert scale items are depicted in Table 3. 
Table I Socio-Demographic Characteristics of the Respondents

\begin{tabular}{|c|c|c|}
\hline Variables & Frequency $(n=2 \mid 9)$ & Percentage (\%) \\
\hline \multicolumn{3}{|l|}{ Gender } \\
\hline Male & 135 & 61.6 \\
\hline Female & 84 & 38.4 \\
\hline \multicolumn{3}{|l|}{ Age } \\
\hline 15_20 & 29 & 13.2 \\
\hline $21 \_30$ & 46 & 21.0 \\
\hline 3I_40 & 27 & 12.3 \\
\hline 4I_50 & 36 & 16.4 \\
\hline $51 \_60$ & 43 & 19.6 \\
\hline Above_60 & 38 & 17.4 \\
\hline \multicolumn{3}{|l|}{ Residence } \\
\hline Urban & 65 & 29.7 \\
\hline Rural & 154 & 70.3 \\
\hline \multicolumn{3}{|l|}{ Marital Status } \\
\hline Married & 155 & 70.8 \\
\hline Divorced & 24 & 11.0 \\
\hline Widowed & 9 & 4.1 \\
\hline Single & 31 & 14.2 \\
\hline \multicolumn{3}{|l|}{ Educational Level } \\
\hline No Formal Education & 119 & 54.3 \\
\hline Primary Education & 57 & 26.0 \\
\hline Secondary Education & 21 & 9.6 \\
\hline College And Above & 22 & 10.0 \\
\hline \multicolumn{3}{|l|}{ Occupational Level } \\
\hline Government Employee & 11 & 5.0 \\
\hline Private Employee & 31 & 14.2 \\
\hline Daily Laborer & 20 & 9.1 \\
\hline Farmer & 117 & 53.4 \\
\hline Others & 40 & 18.3 \\
\hline \multicolumn{3}{|l|}{ Who supports you } \\
\hline Parents & 45 & 20.5 \\
\hline Self & 16 & 7.3 \\
\hline Husband/Wife & 101 & 46.1 \\
\hline Others & 57 & 26.1 \\
\hline
\end{tabular}

\section{Factor Affecting Patient Satisfaction with Pharmaceutical Care}

Multivariate logistic regression revealed having assignment of particular clinical pharmacist, previous admission, number of medications per day and length of hospital stay were significantly associated with level of patient satisfaction.

Accordingly, patients who had no previous history of admission were 54.1 times less likely to be dissatisfied with PC service as those who had previous history of admission (AOR: $0.459,95 \%$ CI: 0.244, 0.864). Patients who had no specific clinical pharmacist heir were 2.1 times more likely to
Table 2 Patient and Admission Related Characteristics of the Respondents

\begin{tabular}{|l|l|l|l|}
\hline Items & & Frequency & Percentage \\
\hline History of previous & Yes & 113 & 51.6 \\
Admission & No & 106 & 48.4 \\
\hline $\begin{array}{l}\text { Presence of } \\
\text { Comorbidities }\end{array}$ & Yes & 190 & 86.8 \\
\hline No & 29 & 13.2 \\
\hline Presence of Adverse & Yes & 42 & 19.2 \\
Effect & No & 177 & 80.8 \\
\hline Particular Clinical & Yes & 154 & 70.3 \\
pharmacist Heir & No & 65 & 29.7 \\
\hline Number of medications & $\leq 3$ drugs & 143 & 65.3 \\
per day & $>3$ drugs & 76 & 34.7 \\
\hline Length of hospital stay & $\leq 2$ Weeks & 106 & 48.4 \\
& $3-4$ Weeks & 77 & 35.2 \\
& $>4$ Weeks & 36 & 16.4 \\
\hline Presence of DTP & Yes & 66 & 30.1 \\
& No & 153 & 69.9 \\
\hline
\end{tabular}

be dissatisfied than those who have a particular clinical Pharmacist heir (AOR: 2.091, 95\% CI: 1.028, 4.255). Similarly, patients who took more than three drugs per day were 1.9 times more likely to be dissatisfied than those who took less than or equal to three drugs (AOR: 1.929, 95\% CI: $1.996,3.739)$. Moreover, patients who stayed more than four weeks or between 3-4 weeks in the hospital were 3.1 times (AOR: 3.079, 95\% CI: 1.175, 8.069) and 2.2 times, respectively, more likely to be dissatisfied than those who stayed less than or equal to two weeks (AOR: 2.236, 95\% CI: 1.124, 4.446) (Table 4).

\section{Discussion}

An evaluation of patient satisfaction with service provided in the health care system has been globally recognized as the measure of health care service quality. ${ }^{22-24}$ However, there is a lack of research findings that indicate patient satisfaction with newly implemented PC service, particularly in developing countries including Ethiopia. In addition, it has recently been suggested that the quality of PC is closely linked to patient satisfaction as it will affect therapeutic outcome and patient retentions. ${ }^{30-32}$ Moreover, understanding patient satisfaction with pharmacy services can be very helpful to enhance the quality and monitoring of PC services. ${ }^{33}$ 


\section{Types of Drug Therapy Problem}

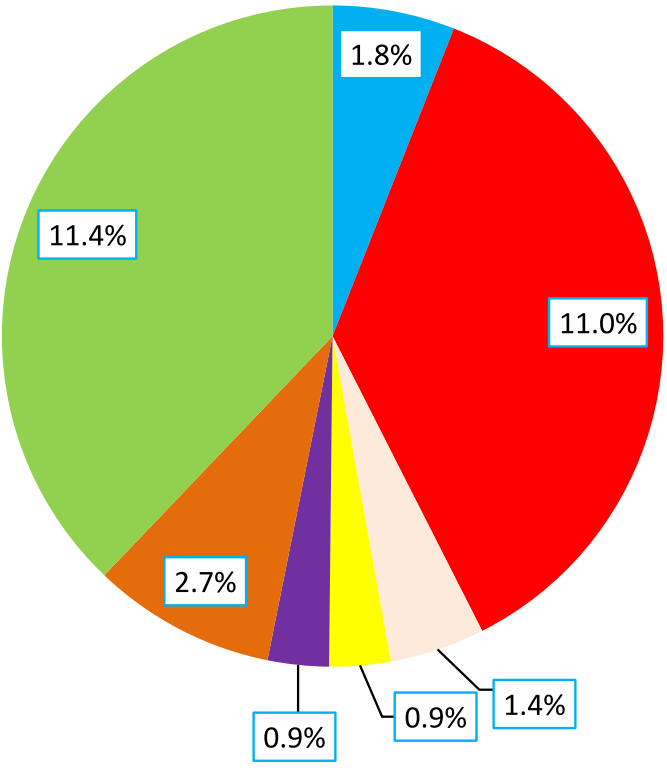

- Un Necessary Drug Therapy

- Needs Additional Drug Therapy

In-effective Drug Therapy

Dosage Too Low

- Adverse Reaction

Dosage Too High

Non-Adherence

Figure I Types of DTPs documented.

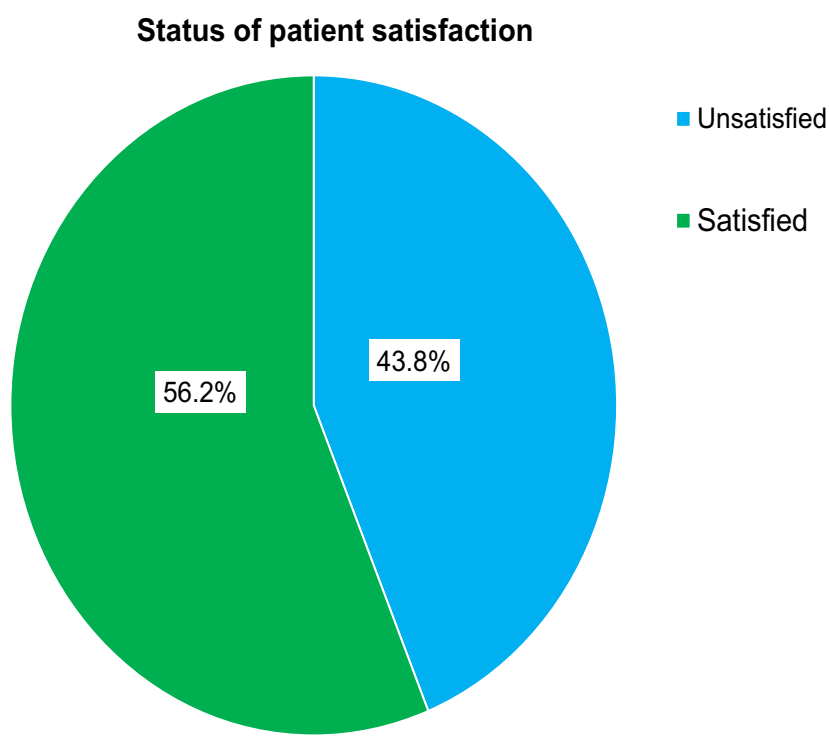

Figure 2 Status of patient satisfaction with PC services.

Thus, assessing the patient satisfaction with PC service will help to fill the gap between patients need and the services provided. In this study, more than half of the respondents $(56.2 \%)$ were satisfied with the newly implemented PC service. This finding is slightly lower than a study conducted at Dessie Town Hospitals $(59.4 \%) .{ }^{34}$ However, it is higher than study carried out at Yekatit 12 Medical College Hospital (47\%), ${ }^{35}$ Gondar University Referral Hospital $(49.6 \%)^{36}$ and the public hospitals of western and eastern Hararghe zone $(6.19 \%)^{37}$ in Ethiopia. This variation could be related to the difference in scope of the study, in which the current study assessed the PC in terms of pharmacistdirect contact with patients, clinical pharmacy services while comparative studies were based on usual pharmacy service, concentrating on the out-patient pharmacy services. Moreover, the present finding is lower when compared with findings in Spain (84\%), ${ }^{38}$ USA $(69 \%),{ }^{39}$ and Australia (99.5\%). ${ }^{40}$ This difference may be due to economic conditions, as the developed counties have more advanced PC practice than developing country like Ethiopia. More specifically, in the present study, the majority of patients responded satisfied to verysatisfied for items like satisfaction with medication reconciliation, counselling of storage condition and instructions, and time spent with pharmacist. This finding is consistent with a study reported in Canada that patients have valued the pharmacist's initiative to meet them in the clinic, the education provided by pharmacist, and the pharmacist's accessibility throughout treatment. $^{39,41-43}$ On the other hand, around $44 \%$ of patients were not satisfied with PC service. This patient dissatisfaction may be due to lack of particular clinical pharmacist assignment, history of previous admission, number of medications taken per day and length of hospital stay. As such, patients who had no specific 
Table 3 Evaluation of the Patient Satisfaction Using a 5-Point Likert Scale

\begin{tabular}{|c|c|c|c|c|c|}
\hline $\begin{array}{l}\text { Items for Assessment of the Level of Patients Satisfaction with } \\
\text { Pharmaceutical Care }\end{array}$ & $\begin{array}{l}\text { Very } \\
\text { Satisfied } \\
\text { n(\%) }\end{array}$ & $\begin{array}{l}\text { Satisfied } \\
\text { n (\%) }\end{array}$ & $\begin{array}{l}\text { Neutral } \\
\text { n(\%) }\end{array}$ & $\begin{array}{l}\text { Dissatisfied } \\
\mathbf{n}(\%)\end{array}$ & $\begin{array}{l}\text { Very } \\
\text { Dissatisfied } \\
\text { n(\%) }\end{array}$ \\
\hline $\begin{array}{l}\text { How much you are satisfied with medication reconciliation services (list } \\
\text { of medication including vitamins, supplements, herbal and traditional } \\
\text { medicines), route, indication, instructions) provided by Clinical } \\
\text { pharmacist? }\end{array}$ & $8(3.7)$ & $79(36.1)$ & $46(21.0)$ & $84(38.4)$ & $2(0.9)$ \\
\hline $\begin{array}{l}\text { How much you satisfied with Clinical pharmacist action to assess } \\
\text { duplications or potential interactions of medication? }\end{array}$ & 14(6.4) & $27(12.3)$ & $86(39.3)$ & $91(4 I .6)$ & $\mathrm{I}(0.5)$ \\
\hline $\begin{array}{l}\text { How much you satisfied with medication changes, the reason for the } \\
\text { change, counsel regarding new medications by Clinical pharmacist? }\end{array}$ & $12(5.5)$ & $16(7.3)$ & $107(48.9)$ & $80(36.5)$ & $4(1.8)$ \\
\hline $\begin{array}{l}\text { How much you satisfied with counselling of Clinical pharmacist on } \\
\text { storage condition of drugs and instructions to use them }\end{array}$ & $26(11.9)$ & $127(58.0)$ & $34(15.5)$ & $25(11.4)$ & $7(3.2)$ \\
\hline $\begin{array}{l}\text { How much you satisfied with recommendation of Clinical pharmacist on } \\
\text { lifestyle modification }\end{array}$ & II (5.0) & $32(14.6)$ & $79(36.1)$ & $96(43.8)$ & $\mathrm{I}(0.5)$ \\
\hline $\begin{array}{l}\text { How much you satisfied with effort of Clinical pharmacist to encourage } \\
\text { you on adherence using special tools, logs, devices, booklets, and } \\
\text { brochures }\end{array}$ & $\mathrm{II}(5.0)$ & $6(2.7)$ & $15(6.8)$ & $129(58.9$ & $58(26.5)$ \\
\hline How much you satisfied with time you spent with Clinical pharmacist & $38(17.4)$ & I56(7I.2) & $20(9.1)$ & $4(1.8)$ & $\mathrm{I}(0.5)$ \\
\hline
\end{tabular}

clinical pharmacist assignment were 2.1 times likely to be dissatisfied than those who have a particular clinical pharmacist assignment. This finding is consistent with other studies that have shown the benefits of including clinical pharmacists in the multidisciplinary health care team. $^{44-46}$ Similarly, patients who took more than three drugs per day were 1.9 times likely to be dissatisfied than those who took less than or equal to three drugs. This particular factor agrees with results obtained from the present finding as nonadherence is the most prevalent $(11.4 \%)$ drug therapy identified by clinical pharmacists. This may indicate the evidence of provision of PC service in this health care facility. Moreover, patients who stayed more than four weeks in the hospital were 3.1 times and who stayed between 3-4 weeks were 2.2 times more likely to be dissatisfied than those who stayed less than or equal to two weeks. This finding is consistent with a recent study that showed that the patient satisfaction is highly affected by length of hospital stay. ${ }^{47,48}$ Overall, patient satisfaction can be enhanced by assigning a particular clinical pharmacist and collaborating with a multidisciplinary team, like physicians and nurses since history of previous admissions and length hospital stay may be due to a problem of all health professionals.

\section{Limitation of the Study}

As the current study was cross-sectional, it is difficult to observe the temporal link between patient satisfaction and its associated factors. Thus, the cautious interpretations and generation of the results are important.

\section{Conclusion}

The present study revealed that patient satisfaction towards PC was low. Lack of specific clinical pharmacist assignment, previous history of admission, number of medications taken per day and length of hospital stay are revealed as the major factors affecting the level of satisfaction. In addition, current findings implicate that clinical pharmacists collaboration with a multidisciplinary team is essential to increase patient satisfaction. Therefore, the authors recommend increasing the number of clinical pharmacy staff and collaborating with multidisciplinary team in medical wards to improve overall quality of health care 
Table 4 Predictors of Patient Satisfaction with PC

\begin{tabular}{|c|c|c|c|c|c|}
\hline \multirow[t]{2}{*}{ Study Variables } & \multicolumn{2}{|c|}{ Level of Satisfaction (\%) } & \multirow[t]{2}{*}{ COR $(95 \% \mathrm{Cl})$} & \multirow[t]{2}{*}{ AOR $(95 \% \mathrm{Cl})$} & \multirow[t]{2}{*}{ P-value } \\
\hline & Unsatisfied & Satisfied & & & \\
\hline \multicolumn{6}{|l|}{ Educational Level } \\
\hline No Formal Education & $60(62.5 \%)$ & 59 (48.0\%) & I & I & 0.039 \\
\hline Primary Education & $23(24.0 \%)$ & $34(27.6 \%)$ & $1.555(0.820,2.948)$ & $0.838(0.358,1.963)$ & \\
\hline Secondary Education & $9(9.4 \%)$ & $12(9.8 \%)$ & $1.402(0.550,3.576)$ & $0.283(0.075,1.065)$ & \\
\hline College And Above & $4(4.2 \%)$ & $18(14.6 \%)$ & $4.733(I .5 \mid I, I 4.820)^{*}$ & $4.024(0.679,23.849)$ & \\
\hline \multicolumn{6}{|l|}{ Have clinical pharmacist heir } \\
\hline Yes & 75 (78.1\%) & $79(64.2 \%)$ & I & I & 0.040 \\
\hline No & $21(21.9 \%)$ & $44(35.8 \%)$ & $2.042(\mathrm{I} .1 \mathrm{II}, 3.75 \mathrm{I})^{*}$ & $2.091(1.028,4.255)^{*}$ & \\
\hline \multicolumn{6}{|l|}{ Previous admission } \\
\hline Yes & $4 \mathrm{I}(42.7 \%)$ & $72(58.5 \%)$ & I & I & 0.016 \\
\hline No & $55(57.3 \%)$ & $51(41.5 \%)$ & $0.549(0.320,0.94 I)^{*}$ & $0.459(0.244,0.864)^{*}$ & \\
\hline \multicolumn{6}{|l|}{ Presences of comorbidities } \\
\hline Yes & $90(93.8 \%)$ & $100(81.3 \%)$ & I & I & 0.148 \\
\hline No & $6(6.2 \%)$ & $23(18.7 \%)$ & $3.524(1.373,9.043)^{*}$ & $2.206(0.756,6.439)$ & \\
\hline \multicolumn{6}{|l|}{ Presence of Adverse Effect } \\
\hline Yes & $19(19.8 \%)$ & $23(18.7 \%)$ & 1 & 1 & 0.450 \\
\hline No & $77(80.2 \%)$ & $100(81.3 \%)$ & $1.048(0.533,2.062)$ & $1.378(0.600,3.168)$ & \\
\hline \multicolumn{6}{|l|}{ Number of medications per day } \\
\hline$\leq 3$ drugs & $7 I(74.0 \%)$ & $72(58.5 \%)$ & 1 & 1 & \\
\hline$>3$ drugs & $25(26.0 \%)$ & $51(41.5 \%)$ & $1.896(1.066,3.374)^{*}$ & $1.929(1.996,3.739)^{*}$ & 0.048 \\
\hline \multicolumn{6}{|l|}{ Length of hospital stay } \\
\hline$\leq 2$ Weeks & $55(57.3 \%)$ & $5 \mathrm{I}(4 \mathrm{I} .5 \%)$ & I & I & \\
\hline 3-4 Weeks & $31(32.3 \%)$ & $77(35.2 \%)$ & $1.662(0.918,3.010)^{*}$ & $2.236(1.124,4.446)^{*}$ & 0.018 \\
\hline >4 Weeks & $10(10.4 \%)$ & $26(21.1 \%)$ & $2.912(1.279,6.632)^{*}$ & $3.079(1.175,8.069) *$ & \\
\hline
\end{tabular}

Note: *Statistically significant at $95 \% \mathrm{Cl}$.

Abbreviations: $\mathrm{Cl}$, Confidence Interval; COR, Crude Odd Ratio, AOR, Adjusted Odd Ratio.

service. Moreover, further research should be undertaken on multi-domain dimensions like facility design that covers all health professionals in Ethiopia.

\section{Abbreviations}

DTP, Drug Therapy Problem; JUMC, Jimma University Medical Center; PC, Pharmaceutical Care; WHO, World Health Organization.

\section{Data Sharing Statement}

The documents supporting this study will be available upon request from the corresponding author.

\section{Ethical Approval and Consent to Participate}

The Helsinki declarations were followed for undertaking this study. Institutional review board of Jimma University,
School of Pharmacy (Reference Number, IoH/SoP/04/ 2021) approved the study. A letter of permission was received from the Office of Chief Executive Officer of Jimma University Medical Center. The written informed consent of the study participants was taken prior to interviews for collection of data. The withdrawal right of study participants from involvements of study at any time was assured.

\section{Acknowledgments}

The authors would like to extend the heartfelt gratitude to all study respondents for accepting invitation to be involved in this study.

\section{Author Contributions}

Both authors contributed to data analysis, drafting or revising the article, gave final approval of the version to 
be published, agreed to the submitted journal, and agree to be accountable for all aspects of the work.

\section{Disclosure}

The authors report no conflicts of interest in this work.

\section{References}

1. Pearson GJ. Evolution in the practice of pharmacy - not a revolution! CMAJ. 2007;176(9):1295-1296. doi:10.1503/cmaj.070041

2. Hepler CD, Strand LM. Opportunities and responsibilities in pharmaceutical care. Am J Hosp Pharm. 1990;47(3):533-543.

3. Allemann SS, Van Mil JWF, Botermann L, Berger K, Griese N, Hersberger KE. Pharmaceutical care: the PCNE definition 2013. Int J Clin Pharm. 2014;36(3):544-555. doi:10.1007/s11096-0149933-x

4. Wang X, Pang Y, Wang M, Jing J, Tang J. Clinical practice and teaching of pharmaceutical care procedures for obstetric diseases. Eur J Hosp Pharm. 2020; ejhpharm-2019-002053. doi:10.1136/ejhpharm-2019-002053

5. Van Mil JWF, Schulz M, Tromp TFJ. Pharmaceutical care, European developments in concepts, implementation, teaching, and research: a review. Pharm World Sci. 2004;26(6):303-311. doi:10.1007/s11096004-2849-0

6. Silva BB, Fegadolli C. Implementation of pharmaceutical care for older adults in the brazilian public health system: a case study and realistic evaluation. BMC Health Serv Res. 2020;20(1):1-14. doi:10.1186/s12913-020-4898-z

7. Awad A, Al-Ebrahim S, Abahussain E. Pharmaceutical care services in hospitals of Kuwait. J Pharm Pharm Sci. 2006;9(2):149-157.

8. World Health Organization. New tool to enhance role of pharmacists in health care GENEVA2006. Available from: https://www.who.int/ mediacentre/news/new/2006/nw05/en/. Accessed July 29, 2021.

9. Chamorro-de-vega E, Rodríguez-González CG, Giménez-Manzorro Á, Herranz A, Sanjurjo M. Hepatitis $\mathrm{C}$ virus infection and the role of a pharmaceutical care program. Am J Heal Pharm. 2020;77 (6):479-486. doi:10.1093/ajhp/zxz266

10. Botts SR, Gee MT, Chang CC, Young I, Saito L, Lyman AE. Design and implementation of population-based specialty care programs. Am J Heal Pharm. 2017;74(18):1437-1445. doi:10.2146/ajhp161016

11. Patel K, Chim YL, Grant J, Wascher M, Nathanson A, Canfield S. Development and implementation of clinical outcome measures for automated collection within specialty pharmacy practice. J Manag Care Spec Pharm. 2020;26(7):901-909.

12. Campos Fernández de Sevilla MÁ, Gallego Úbeda M, Heredia Benito $\mathrm{M}$, et al. Implementation of a pharmaceutical care program for patients with hepatitis $\mathrm{C}$ treated with new direct-action antivirals. Int J Clin Pharm. 2019;41(2):488-495. doi:10.1007/s11096-01900809-3

13. Haramiova Z, Stasko M, Hulin M, Tesar T, Kuzelova M, Morisky DM. The effectiveness of daily SMS reminders in pharmaceutical care of older adults on improving patients' adherence to antihypertensive medication (SPPA): study protocol for a randomized controlled trial. Trials. 2017;18(1):1-15. doi:10.1186/ s13063-017-2063-8

14. Margusino-Framiñán L, Cid-Silva $\mathrm{P}$, Martínez-Roca $\mathrm{C}$, et al. Implementation of specialized pharmaceutical care hospital outpatient clinics in a hospital pharmacy department. Farm Hosp. 2017;41 (6):660-666.

15. Chen B, Huang -J-J, Chen H, Xu B. Clinical pharmacy service practice in a Chinese tertiary hospital. Drug Metab Pers Ther. 2015;30(4):215-230.
16. Zheng S, Yang L, Zhou P, Li H, Liu F, Zhao RR. Recommendations and guidance for providing pharmaceutical care services during COVID-19 pandemic: a China perspective. Res Social Adm Pharm. 2021;17(1):1819-1824. doi:10.1016/j.sapharm.2020.03.012

17. Obreli-Neto PR, Marusic S, Guidoni CM. Economic evaluation of a pharmaceutical care program for elderly diabetic and hypertensive patients in primary health care: a 36-month randomized controlled clinical trial. J Manag Care Pharm. 2015;21(1):66-75.

18. Etemad LR, Hay JW. Cost-effectiveness analysis of pharmaceutical care in a medicare drug benefit program. Value Health. 2003;6 (4):425-435. doi:10.1046/j.1524-4733.2003.64255.x

19. Dalton K, Byrne S. Role of the pharmacist in reducing healthcare costs: current insights. Integr Pharm Res Pract. 2017;6:37-46. doi:10.2147/IPRP.S108047

20. Asamrew N, Endris AA, Tadesse M. Level of patient satisfaction with inpatient services and its determinants: a study of a specialized hospital in Ethiopia. J Environ Public Health. 2020;2020:1-12. doi:10.1155/2020/2473469

21. Lima T, Aguiar PM, Storpirtis S. Evaluation of quality indicator instruments for pharmaceutical care services: a systematic review and psychometric properties analysis. Res Soc Adm Pharm. 2018;14 (5):405-412. doi:10.1016/j.sapharm.2017.05.011

22. Xesfingi S, Vozikis A. Patient satisfaction with the healthcare system: assessing the impact of socio-economic and healthcare provision factors. BMC Health Serv Res. 2016;16(1):1-7. doi:10.1186/s12913-016-1327-4

23. Umoke M, Umoke PCI, Nwimo IO, et al. Patients' satisfaction with quality of care in general hospitals in Ebonyi State, Nigeria, using SERVQUAL theory. SAGE Open Med. 2020;8:205031212094512. doi:10.1177/2050312120945129

24. Aga TB, Ferede YM, Mekonen EG. Satisfaction and associated factors towards inpatient health care services among adult patients at Pawie General Hospital, West Ethiopia. PLoS One. 2021;16 (4April):1-11. doi:10.1371/journal.pone.0249168

25. Bilal AI, Tilahun Z, Beedemariam G, Ayalneh B, Hailemeskel B, Engidawork E. Attitude and satisfaction of health care providers towards clinical pharmacy services in Ethiopia: a post-deployment survey. JPharm Policy Pract. 2016;9(1):1-14. doi:10.1186/s40545-016-0058-6

26. Ethiopian Ministry of Health. National clinical pharmacy service implementation manual in Ethiopia; 2018:1-112. Available from: http://www.moh.gov.et/ejcc/sites/default/files/2019-06/ NationalClinicalPharmacyServiceImplementationManual.pdf. Accessed September 8, 2021.

27. Abebe TB, Erku DA, Gebresillassie BM, Haile KT, Mekuria AB. Expectation and satisfaction of HIV/AIDS patients toward the pharmaceutical care provided at Gondar University referral hospital, northwestern Ethiopia: a Cross-Sectional Study. Patient Prefer Adherence. 2016;10:2073-2082. doi:10.2147/PPA.S114720

28. Jimma University. Available from: https:/www.ju.edu.et/?q=article/ specialized-hosptial. Accessed April, 2020.

29. Raosoft ${ }^{\circledR}$ Sample Size Calculator. Available from: http://www.raosoft. com/samplesize.html. Accessed April, 2020.

30. Ji HJ, Yue F, Song J, Zhou X. Quality of pharmaceutical care is closely associated with patient satisfaction. Eur J Hosp Pharm. 2019;26(4):238-239. doi:10.1136/ejhpharm-2018-001732

31. Minarikova D, Malovecka I, Foltan V. Patient choice of pharmacy and satisfaction with pharmaceutical care - Slovak regional comparison. Farmacia. 2016;64(3):473-480.

32. Hassali MA, Saleem F, Verma AK, Choy WY, Nouri AI, Asmani MFM. Translation and validation of patient satisfaction with pharmacist services questionnaire (PSPSQ 2.0). J Young Pharm. 2018;10(4):427-432. doi:10.5530/jyp.2018.10.94

33. Shrestha S, Sapkota B, Thapa S, Bhuvan KC, Khanal S. Translation, cross-cultural adaptation and validation of patient satisfaction with pharmacist services questionnaire (PSPSQ 2.0) into the Nepalese version in a community settings. PLoS One. 2020;15(10):1-15. doi:10.1371/journal.pone.0240488 
34. Kebede H, Tsehay T, Necho M, Zenebe Y. Patient satisfaction towards outpatient pharmacy services and associated factors at Dessie town public hospitals, south Wollo, North-East Ethiopia. Patient Prefer Adherence. 2021;15:87-97. doi:10.2147/PPA. S287948

35. Berehe TT, Bekele GE, Yimer YS, Lozza TZ. Assessment of clients satisfaction with outpatient services at Yekatit 12 Hospital Medical College, Addis Ababa, Ethiopia. BMC Res Notes. 2018;11(1):1-6. doi:10.1186/s13104-018-3603-3

36. Surur AS, Teni FS, Girmay G, Moges E, Tesfa M, Abraha M. Satisfaction of clients with the services of an outpatient pharmacy at a university hospital in northwestern Ethiopia: a Cross-Sectional Study health systems and services in low and middle income settings. BMC Health Serv Res. 2015;15(1):1-8. doi:10.1186/s12913-015-0900-6

37. Ayele Y, Hawulte B, Feto T, Basker GV, Bacha YD. Assessment of patient satisfaction with pharmacy service and associated factors in public hospitals, Eastern Ethiopia. SAGE Open Med. 2020;8:205031212092265. doi:10.1177/2050312120922659

38. Ribed A, Romero-Jiménez RM, Escudero-Vilaplana V, et al. Pharmaceutical care program for onco-hematologic outpatients: safety, efficiency and patient satisfaction. Int J Clin Pharm. 2016;38 (2):280-288. doi:10.1007/s11096-015-0235-8

39. Martin MT, Faber DM. Patient satisfaction with the clinical pharmacist and prescribers during hepatitis $\mathrm{C}$ virus management. J Clin Pharm Ther. 2016;41(6):645-649. doi:10.1111/jcpt.12436

40. Burt S, Hattingh L, Czarniak P. Evaluation of patient satisfaction and experience towards pharmacist-administered vaccination services in Western Australia. Int J Clin Pharm. 2018;40(6):1519-1527. doi:10.1007/s11096-018-0738-1

41. Munro L, Myers G, Gould O, LeBlanc M. Clinical pharmacy services in an ambulatory oncology clinic: patient perception and satisfaction. J Oncol Pharm Pract. 2020;27(5):1086-93.
42. Crespo A, Tyszka M. Evaluating the patient-perceived impact of clinical pharmacy services and proactive follow-up care in an ambulatory chemotherapy unit. J Oncol Pharm Pract. 2017;23 (4):243-248. doi:10.1177/1078155216634180

43. Martinez-lopez-de-castro N, Álvarez-payero M, Martín-Vila A, et al. Factors associated with patient satisfaction in an outpatient hospital pharmacy. Eur J Hosp Pharm. 2018;25(4):183-188. doi:10.1136/ ejhpharm-2016-001192

44. McNeely EB. Treatment considerations and the role of the clinical pharmacist throughout transitions of care for patients with acute heart failure. $J$ Pharm Pract. 2017;30(4):441-450. doi:10.1177/ 0897190016645435

45. Dunn SP, Birtcher KK, Beavers CJ, et al. The role of the clinical pharmacist in the care of patients with cardiovascular disease. $J \mathrm{Am}$ Coll Cardiol. 2015;66(19):2129-2139. doi:10.1016/j. jacc.2015.09.025

46. Zhang J, Li X, Xie J, Zheng W. Evaluation of a clinical pharmacist consultation service for patients with infectious diseases in China: a systematic review and meta-analysis. Eur J Hosp Pharm. 2020;27 (3):131-136. doi:10.1136/ejhpharm-2018-001815

47. Diwan W, Nakonezny PA, Wells J. The effect of length of hospital stay and patient factors on patient satisfaction in an academic hospital. Orthopedics. 2020;43(6):373-379. doi:10.3928/0147744720200910-02

48. Gonçalves-Bradley DC, Lannin NA, Clemson LM, Cameron ID, Shepperd S. Discharge planning from hospital. Cochrane Database Syst Rev. 2016;2016(1):CD000313.
Patient Preference and Adherence

\section{Publish your work in this journal}

Patient Preference and Adherence is an international, peer-reviewed, open access journal that focusing on the growing importance of patient preference and adherence throughout the therapeutic continuum. Patient satisfaction, acceptability, quality of life, compliance, persistence and their role in developing new therapeutic modalities and compounds to optimize clinical outcomes for existing disease

\section{Dovepress}

states are major areas of interest for the journal. This journal has been accepted for indexing on PubMed Central. The manuscript management system is completely online and includes a very quick and fair peer-review system, which is all easy to use. Visit http:// www.dovepress.com/testimonials.php to read real quotes from published authors. 